\title{
PENGARUH KUALITAS LAYANAN TERHADAP KEPUASAN KONSUMEN RESTO \& CAFÉ RUMAH LAUT JAYAPURA
}

\author{
Risma \\ IAIN Fatahul Muluk Papua \\ e-mail: rismakyuri85@gmail.com \\ Syaiful Muhyidin \\ IAIN Fatahul Muluk Papua \\ e-mail: syaifulmuhyidin@gmail.com \\ Ira Eka Pratiwi \\ IAIN Fatahul Muluk Papua \\ e-mail: pratiwi.iraeka@khu.ackr
}

\begin{abstract}
Nowadays, the existence of cafes can be found anywhere, including in Jayapura city. One of the popular cafes in Jayapura is Resto \& Café Rumah Laut. Service quality considered in the cafe business because it is related to consumer satisfaction. The problem statement in this study is how does the service quality (physical evidence, reliability, responses, guarantees, and empathy) affects the satisfaction of consumers in the Resto \& Café Rumah Laut Jayapura. The purpose of this study was to analyze the effect of service quality partially and simultaneously on consumer satisfaction in Resto \& Café Rumah Laut Jayapura.

The study was conducted using the Service Quality (SERVQUAL) model. The research method used is quantitative statistics with multiple linear regression analysis. The data collected by using a questionnaire which has tested its validity and reliability from 60 respondent of the Resto \& Café Rumah Laut Jayapura.

The result of the study shows that consumer satisfaction variable can be explained by the service quality by $63,7 \%$, while the remaining $36,3 \%$ is explained by other factors. Meanwhile, the $\mathrm{f}$ test shows that the f-count value is greater than the $\mathrm{f}$ table value $(18.919>2.38)$ with the level of significance is $0.000<0.05$ means that the quality of service simultaneously has a significant effect on consumer satisfaction. Furthermore, the results of the t-test showed that the physical evidence and guarantee variables partially affected consumer satisfaction, with the level of significance is 0.048 $<0.05$ and $0.009<0.05$, respectively. While the reliability variable had the level of significance by 0.051 , the responses variable had the level of significance by 0.666 and the empathy variable had the level of significance by 0.098 partially does not significantly influence the consumer satisfaction variable.
\end{abstract}

Keywords: Service Quality, Consumer Satisfaction, Jayapura, Café 


\begin{abstract}
Abstrak
Saat ini, keberadaan kafe dapat ditemukan di mana saja, termasuk di kota Jayapura. Salah satu kafe populer di Jayapura adalah Resto \& Café Rumah Laut. Kualitas layanan dipertimbangkan dalam bisnis kafe karena terkait dengan kepuasan konsumen. Pernyataan masalah dalam penelitian ini adalah bagaimana kualitas layanan (bukti fisik, keandalan, tanggapan, jaminan, dan empati) mempengaruhi kepuasan konsumen di Resto \& Café Rumah Laut Jayapura. Tujuan dari penelitian ini adalah untuk menganalisis pengaruh kualitas layanan secara parsial dan simultan terhadap kepuasan konsumen di Resto \& Café Rumah Laut Jayapura.

Penelitian dilakukan dengan menggunakan model Service Quality (SERVQUAL). Metode penelitian yang digunakan adalah statistik kuantitatif dengan analisis regresi linier berganda. Data dikumpulkan dengan menggunakan kuesioner yang telah diuji validitas dan reliabilitas dari 60 responden Resto \& Café Rumah Laut Jayapura.

Hasil penelitian menunjukkan bahwa variabel kepuasan konsumen dapat dijelaskan oleh kualitas layanan sebesar $63,7 \%$, sedangkan sisanya 36,3\% dijelaskan oleh faktor lain. Sementara itu, uji f menunjukkan bahwa nilai f-hitung lebih besar dari nilai f-tabel $(18,919>2,38)$ dengan tingkat signifikansi $0,000<0,05$ berarti bahwa kualitas layanan secara bersamaan memiliki pengaruh yang signifikan terhadap kepuasan konsumen. Selanjutnya, hasil uji-t menunjukkan bahwa bukti fisik dan variabel jaminan secara parsial mempengaruhi kepuasan konsumen, dengan tingkat signifikansi masing-masing adalah $0,048<0,05$ dan $0,009<0,05$. Sementara variabel reliabilitas memiliki tingkat signifikansi sebesar 0,051, variabel respon memiliki tingkat signifikansi sebesar 0,666 dan variabel empati memiliki tingkat signifikansi sebesar 0,098 secara parsial tidak signifikan mempengaruhi variabel kepuasan konsumen.
\end{abstract}

Kata kunci: Kualitas Layanan, Kepuasan Konsumen, Jayapura, Kafe

\title{
PENDAHULUAN
}

Segala sesuatu pasti mengalami perubahan, termasuk masyarakat dalam kehidupannya. Perubahan yang terjadi mencakup beberapa ruang lingkup, salah satunya yaitu gaya hidup. Perubahan sosial adalah perubahan yang terjadi sebagai suatu variasi dari cara hidup yang telah diterima karena adanya perubahan kondisi geografi, kebudayaan material, komposisi penduduk, ideologi, maupun adanya difusi atau penemuan-penemuan baru dalam masyarakat (Djazifah, 2012). Modernisasi adalah suatu bentuk dari perubahan sosial, yang merupakan transfomasi total dari kehidupan tradisional atau pra modern dalam hal organisasi sosial dan teknologi kearah yang lebih modern, dengan tujuan utama adalah untuk meningkatkan kualitas hidup masyarakat secara umum dan mengubah pola pikir seseorang menjadi lebih baik dalam berbagai bidang kehidupan, sehingga dapat beradaptasi dengan kehidupan yang dinamis.

Arus globalisasi yang semakin pesat menjadikan modernisasi muncul dalam berbagai bentuk, yang dapat kita lihat pada berbagai aspek kehidupan masyarakat. Contohnya dari segi sosial budaya, bentuk modernisasinya seperti kebiasaan masyarakat yang dulunya berkumpul di pos ronda kini mulai beralih untuk berkumpul di kafe yang ada. Kafe telah menjadi bagian dari kebutuhan masyarakat modern. Dalam 
pengembangannya mengarah pada konsumen muda yang selalu ingin mencoba hal baru dan menjadikan kafe bukan hanya sekedar tempat memuaskan rasa lapar atau haus, tetapi sebagai tempat berkumpul dan berinteraksi dengan teman, keluarga atau kerabat lainnya. Fenomena ini memberikan peluang usaha bagi wirausahawan untuk menjadikan hal tersebut sebagai ladang bisnis yang menjanjikan.

Di zaman modern saat ini, perubahan gaya hidup membuat strategi pemasaran dalam bisnis kafe juga mengalami perubahan. Menciptakan produk baru atau menawarkan harga murah seringkali belum juga mencapai hasil yang sesuai harapan. Kedua startegi tersebut hanya bisa memberi keyakinan dan daya dorong beli pada konsumen yang rasional. Padahal tidak semua konsumen cenderung menggunakan alasan rasional sebagai pertimbangan utama dalam memutuskan pembelian. Banyak konsumen yang menggunakan pendekatan emosinya ketika memilih produk. Dalam kondisi seperti ini, pendekatan yang cenderung irasional berupa hubungan baik dengan konsumen menjadi faktor utama (Iqbal, 2004).

Setiap bisnis yang memiliki komitmen yang jujur terhadap layanan pelanggan akan selalu memiliki pelanggan setia karena konsumen tersebut puas. Bisnis seperti ini akan bertumbuh melalui promosi dari mulut ke mulut, dan pelanggan mereka akan tetap setia dalam suka dan duka (Wood, 2009). Kualitas pelayanan merupakan faktor penting untuk memperoleh laba dan kesuksesan perusahaan karena kualitas pelayanan dianggap sebagai salah satu alat untuk dirensiasi pelayanan dan keunggulan kompetitif yang menarik konsumen baru dan berkontribusi terhadap market share.

Perkembangan zaman yang semakin maju tentu terjadi pada seluruh belahan dunia, termasuk di Indonesia. Arus globalisasi yang tidak dapat dihindari membuat modernisasi dapat dengan mudah dijumpai di setiap daerah yang ada di Indonesia, termasuk di Kota Jayapura. Meskipun kota ini berada di ujung paling timur Indonesia, tetapi perkembangan zaman yang modern juga meliputinya. Kini di Jayapura telah banyak kafe yang didirikan dan dibuka sebagai wadah bagi masyarakat untuk berkumpul ataupun menghabiskan waktu luang. Salah satunya adalah Resto \& Cafe Rumah Laut yang terletak di Jalan Koti, Jayapura. Kafe ini memiliki pemandangan laut yang indah dan mendapatkan rating yang tinggi dari konsumen. Dibuktikan dengan rating yang tinggi di website Traveloka dengan nilai 4/5 dan menempati urutan pertama sebagai restoran terpopuler yang wajib dikunjungi di Jayapura berdasarkan website Tripadvisori.

Berdasarkan teori sebelumnya yang mengatakan bahwa salah satu faktor yang membuat konsumen menjadi puas adalah bisnis yang mengutamakan layanan terhadap konsumen,yang didukung oleh beberapa penelitian, seperti penelitian yang dilakukan oleh Dwi Aliyyah Apriyani dan Sunarti, menyatakan bahwa kualitas pelayanan yang indikatornya terdiri dari bukti fisik (tangible), kehandalan (reliability), tanggapan (responsiveness), jaminan (assurance) dan empati (empathy) berpengaruh terhadap kepuasan pelanggan. Oleh karena itu peneliti tertarik untuk meneliti penelitian yang berjudul "Pengaruh Kualitas Layanan Terhadap Kepuasan Konsumen Resto \& Café Rumah Laut Jayapura”. Dalam penelitian ini, teori yang dipakai yaitu kualitas 
pelayanan dengan indikator yang diteliti adalah bukti fisik (tangible), kehandalan (reliability), tanggapan (responsiveness), jaminan (assurance) dan empati (empathy).

Tujuan dari penelitian ini adalah untuk mengetahui dan menganalisis bagaimana pengaruh kualitas layanan secara parsial dan simultan terhadap kepuasan konsumen Resto \& Cafe Rumah Laut Jayapura. Penelitian ini nantinya dapat digunakan oleh wirausaha sebagai media informasi dan gambaran perbaikan atau penyempurnaan usaha yang terkait dengan pengaruh kualitas layanan terhadap kepuasan konsumen pada kafe, sebagai media informasi dan gambaran yang terkait dengan pengaruh kualitas layanan terhadap kepuasan konsumen. Dan tentunya oleh akademik dapat dijadikan sebagai bahan pertimbangan (referensi) dalam ilmu pengetahuan Ekonomi Islam mengenai pengaruh kualitas layanan terhadap kepuasan konsumen.

\section{KAJIAN LITERATUR}

\subsection{Konsep Kualitas Layanan}

a. Pengertian Pelayanan

Secara harfiah pelayanan adalah menolong menyediakan segala apa yang diperlukan orang lain, seperti tamu atau pembeli (Iqbal, 2004). Pelayanan memiliki beberapa karakteristik, yaitu sebagai berikut; pelayanan besifat tidak dapat diraba, pelayanan sangat berlawanan sifatnya dengan barang jadi, pelayanan pada kenyataannya terdiri dari tindakan nyata dan merupakan pengaruh yang bersifat tindakan sosial, kegiatan produksi dan konsumsi dalam pelayan tidak dapat dipisahkan secara nyata, karena pada umumnya terjadi dalam waktu dan tempat bersamaan (Setyabudi, 2014).

b. Kualitas Pelayanan

Kualitas layanan merupakan pemenuhan kebutuhan dan keinginan pelanggan serta ketetapan penyampaiannya untuk mengimbangi harapan pelanggan. Dengan demikian, ada dua faktor utama yang mempengaruhi kualitas layanan, yaitu jasa yang diharapkan (expected service) dan jasa yang dirasakan atau dipersepsikan (perceived value (Kunto, 2013)).

Zeithaml, Bitner dan Gremler mengungkapkan bahwa ada lima dimensi yang dipakai untuk mengukur kualitas pelayanan, yaitu (Sunarti, 2017):

1) Bukti Langsung (Tangible), yaitu berupa penampilan fasilitas fisik, peralatan, pegawai, dan material yag dipasang. Menggambarkan wujud secara fisik dan layanan yang akan diterima oleh konsumen. Contohnya seperti keadaan gedung, fasilitas restoran, desain restoran, dan kerapian penampilan karyawan.

2) Kehandalan (Reliability), yaitu kemampuan untuk memberikan jasa yang dijanjikan dengan handal dan akurat.

3) Tanggapan (Responsiveness), yaitu kemauan untuk membantu konsumen dan memberikan jasa dengan cepat. 
4) Jaminan (Assurance), yaitu pengetahuan, sopan santun, dan kemampuan karyawan untuk menimbulkan keyakinan dan kepercayaan.

5) Empati (Empathy), yaitu kepedulian dan perhatian secara pribadi yang diberikan kepada pelanggan.

c. Model Kualitas Layanan

Diantara model kualitas layanan, yaitu (Chandra, 2019):

1) Total Perceived Quality Model

Berdasarkan model ini, kualitas suatu layanan yang dipersepsikan pelanggan terdiri atas dua dimensi utama, yaitu technical quality berkaitan dengan kualitas output jasa yang dipersepsikan pelanggan dan functional quality berkaitan dengan kualitas cara penyampaian jasa atau menyangkut proses transfer kualitas teknis, output atau hasil akhir jasa dari penyedia jasa kepada pelanggan.

2) Gummesson 40 Model of Offering Quality

Model ini mengasumsikan bahwa layanan dan barang fisik merupakan bagian integral dari jasa yang ditawarkan. Oleh bebab itu, model ini mengintegrasikan elemen barang dan jasa, serta dimaksudkan untuk membantu pengembangan dan pengelolaam kualitas, mencakup tiga variabel; ekspektasi, pengalaman, dan citra.

3) Model Servqual (Service Quality)

Model servqual didasarkan pada asumsi bahwa konsumen membandingkan kinerja layanan pada atribut-atribut relevan dengan standard ideal/ sempurna untuk masing-masing atribut layanan. Bila kinerja sesuai dengan atau melebihi standar, maka persepsi atas kualitas layanan keseluruhan akan positif dan sebaliknya. Dengan kata lain, model ini menganalisis gap antara dua variable pokok, yakni layanan yang diharapkan (espected service) dan jasa yang dipersepsikan (perceiver service). Pengukuran kualitas layanan dalam model servqual didasarkan pada skala multi-item yang dirancang untuk mengukur harapan dan persepsi konsumen, serta gap di antara keduanya pada lima dimensi utama kualitas layanan (rialiabilitas, daya tanggap, jaminan, empati, dan bukti fisik).

d. Pelayanan dalam Perspektif Islam

Pengertian hukum kualitas pelayanan tidak secara langsung dijumpai di dalam Al-Qur'an secara eksplisit, akan tetapi didasarkan pada konsep memberikan pelayanan yang baik kepada manusia itu telah diperintahkan oleh Allah SWT.

Terjemahnya :

"Apabila kamu diberi penghormatan dengan sesuatu penghormatan, Maka balaslah penghormatan itu dengan yang lebih baik dari padanya, atau ballsalah penghormatan itu (dengan yang serupa), Sesungguhnya Allah memperhitungkan segala sesuatu”. (Q.S. An-Nisa/4:86) 
Dari ayat tersebut maka dapat disimpulkan bahwa sesama manusia harus saling menghormati, jika dihubungkan dengna sebuah perusahaan dibidang jasa bias menjadi landasan bagi penyedia jasa untuk menghormati konsumennya. Salah satu bentuk memberikan penghormatan yaitu dengan memberikan kualitas pelayanan yang baik kepada konsumennya.

\subsection{Konsep Kepuasan Konsumen}

a. Pengertian Kepuasan Konsumen

Secara harfiah konsumen adalah orang yang memerlukan, membelanjakan atau menggunakan; pemakai atau pembutuh. Konsumen adalah setiap orang pemakai barang atau jasa yang tersedia dalam masyarakat, baik bagi kepentingan diri sendiri, keluarga, orang lain, maupun makhluk hidup lain dan tidak untuk diperdagangkan.

Menurut pakar pemasaran Kotler Ketler, kepuasana merupakan perasaan senang ataupun kecewa yang muncul karena membandingkan kinerja yang dipersepsikan produk atau hasil terhadap ekspektasi konsumen itu sendiri. Kepuasan konsumen dalam bisnis dianggap sebagai salah satu dimensi kinerja pasar karena peningkatan kepuasan konsumen berpotensi pada pertumbuhan penjualan jangka pendek maupun jangka panjang, serta pangsa pasar sebagai hasil pembelian ulang. Konsep kepuasan konsumen juga bermanfaat untuk mengetahui informasi secara jelas mengenai seberapa puas konsumen terhadap suatu produk atau jasa tertentu (Astut, 2017).

b. Model Kepuasan Konsumen

Secara garis besar, kepuasan pelanggan didasarkan pada tiga teori utama, yaitu (Chandra, 2019):

1) Contrast theory

Berasumsi bahwa konsumen akan membandingkan kinerja produk actual dengan ekspektasi pra-pembelian. Apabila kinerja aktual lebih besar atau sama dengan ekspektasi, maka pelanggan akan puas. Sebaliknya, jika kinerja aktual lebih rendah dibandingkan ekspektasi, maka konsumen akan tidak puas.

2) Assimilation theory

Menyatakan bahwa evaluasi purnabeli merupakan fungsi positf dari ekspektasi konsumen pra-pembelian. Karena proses diskonfirmasi secara psikologis tidak enak dilakukan, konsumen cenderung secara perceptual mendistorsi perbedaan antara ekspektasi dan kinerjanya kearah ekspektasi awal.

3) Assimilation - contrast theory

Teori ini berpegangan bahwa terjadinya edek asimilasi atau efek kontras merupakan fungsi dari tingkat kesenjangan antara kinerja yang diharapkan dan kinerja aktual. 
c. Mengukur Kepuasan Konsumen

Menurut Kotler dalam menentukan tingkat kepuasan konsumen terdapat lima faktor utama yang harus diperhatikan oleh perusahaan, yaitu; kualitas produk, kualitas pelayanan, emosional, harga dan biaya. Menurut Kotler ada beberapa metode yang dapat digunakan dalam melakukan pengukuran keputusan pelanggan, diantaranya yaitu; sistem keluhan dan saran, ghost shopping, lost customer analysis dan survei keputusan pelanggan (Armstrong, 2001).

d. Indikator Kepuasan Konsumen

Sebelum mengukur tingkat kepuasan konsumen, ada aspek-aspek yang bisa menjadi indikator kepuasan konsumen, yaitu ; kepuasan konsumen keseluruhan, dimensi kepuasan pelanggan, konfirmasi ekspektasi (confirmation of expectations), niat beli ulang (repurchase intent), kesediaan untuk merekomendasi (willigness to recommend) dan ketidakpuasan pelanggan (customer dissatisfaction) (Diana, 2019).

e. Manfaat Kepuasan Konsumen

Perusahaan yang sukses dapat memuaskan konsumen mereka. Dengan perkataan lain, konsumen yang tidak puas akan mempengaruhi bisnis secara negatif. Konsumen yang tidak puas akan memberitahukan dua kali hebat kepada orang lain tentang pengalaman buruknya, sedangkan konsumen yang puas akan memberitahukan tentang hal yang terbaik. Konsumen yang puas merupakan aset yang sangat berharga, mereka menciptakan keunggulan daya saing bagi perusahaan (W, 1996).

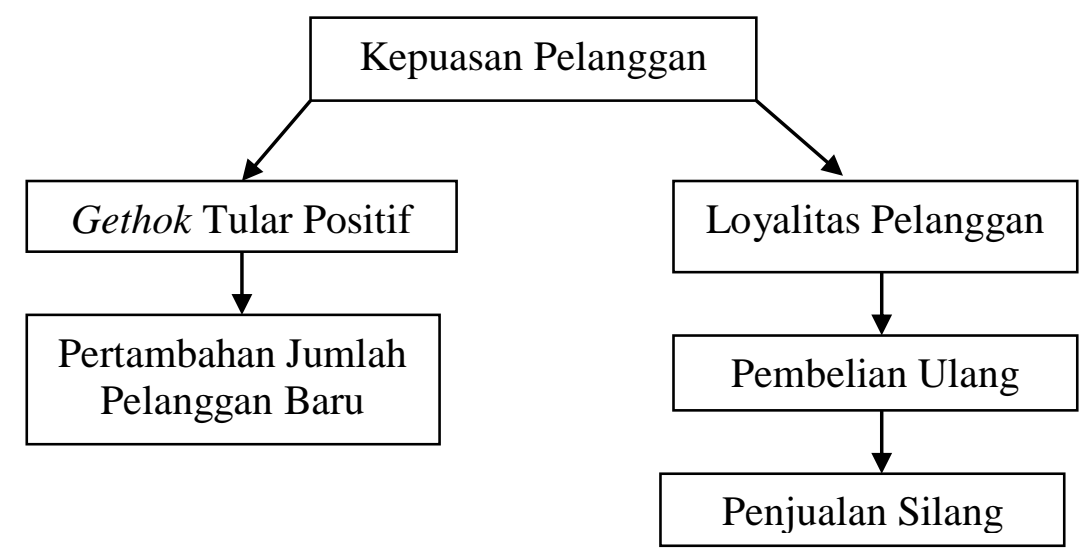

Gambar 1. Manfaat Kepuasan Pelanggan

Lebih rinci, manfaat-manfaat spesifik kepuasan pelanggan bagi perusahaan mencakup : dampak positif pada loyalitas pelanggan; berpotensi menjadi sumber pendapatan masa depan (terutama melalui pembelian ulang, cross-selling, dan up-selling); menekan biaya transaksi pelanggan di masa depan (terutama biaya-biaya komunikasi, penjualan, dan layanan pelanggan); menekan volatilitas dan risiko berkenaan dengan prediksi aliran kas masa depan; meningkatnya toleransi harga (terutama kesediaan untuk membayar 
harga premium dan pelanggan tidak mudah tergoda untuk beralih pemasok); rekomendasi gethok tular positif (Wood, 2009).

f. Kepuasan Konsumen dalam Perspektif Islam

Dari konfigurasi di bawah, ruh, nafs, 'aql, dan qalb yang positif mempengaruhi motivasi konsumen, yakni mencapai kepuasan duniawi dan ukhrawi. Hal ini dalam konfigurasi tripartite Choundhury dinamakan keseimbangan kosmik. Oleh karena pada dasarnya kehendak motivasi berupa kepuasan tersebut baru pada tatanan konseptual, maka dia harus diaktualisasikan ke dalam wilayah praktis. Setiap konsumen dihadapkan pada sejumlah pilihan. Dalam Islam, rumusan menentukan pilihan konsumen bertumpu pada mashlahah yang sedang dihadapi konsumen. Kemudian dari konsep mashlahah tersebut tergambar tiga buah persepsi yang terdiri dari persepsi kebutuhan, persepsi menolak mudharat dan menarik mashlahat, dan persepsi mardhatillah. Hubungan tiga buah persepsi inilah yang menjadi penentu keputusan konsumsi konsumen Muslim (Fauroni, 2006).

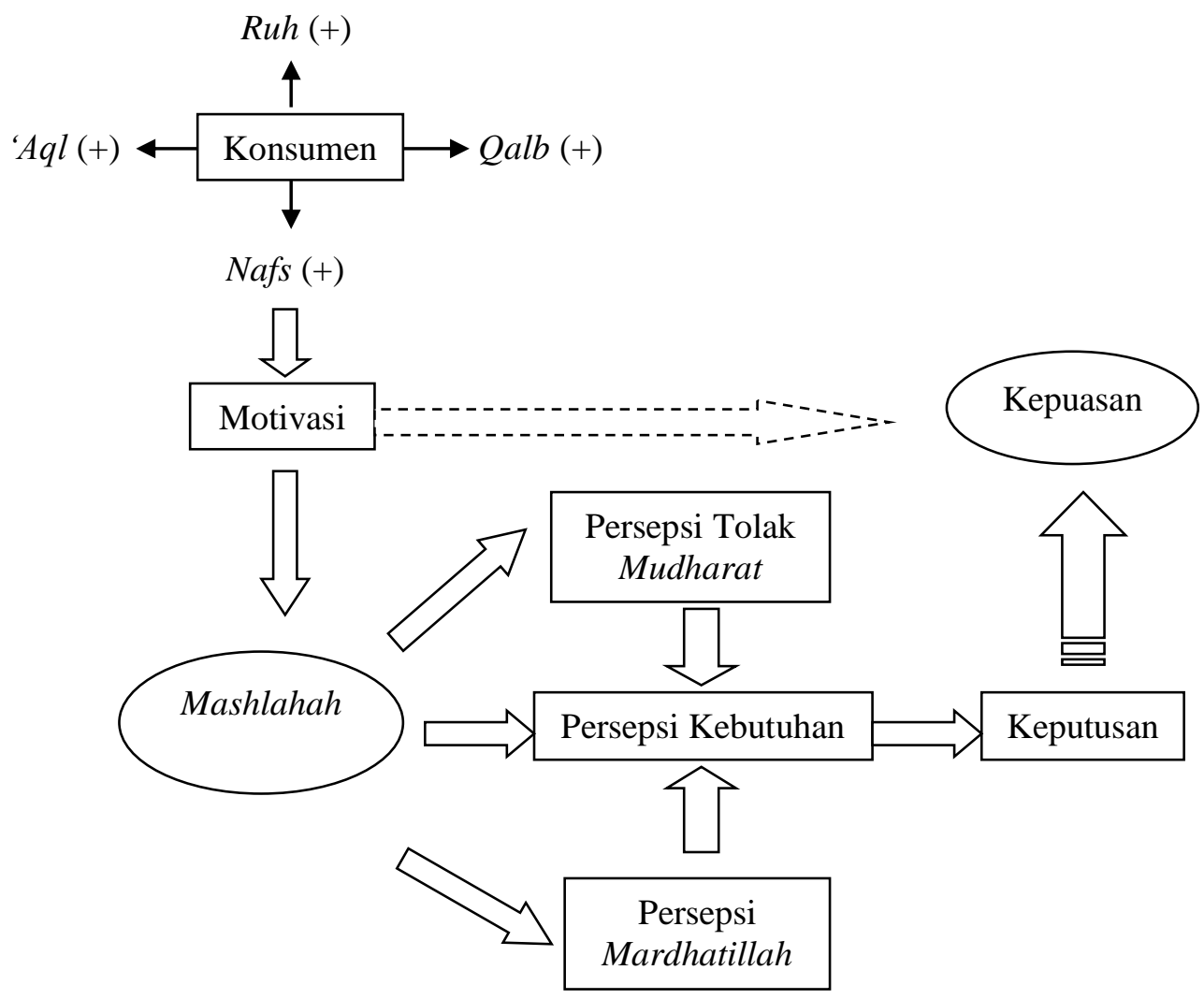

Gambar 2. Proses Terbentuknya Kepuasan Konsumen Muslim

\subsection{Definisi Kafe dan Jenisnya}

Secara terminologis, kata kafé berasal dari bahasa Perancis coffee, yang berarti kopi. Pengertian harafiahnya mengacu pada (minuman) kopi, yang kemudian di Indonesia kafe lebih dikenal sebagai tempat menikmati kopi dengan berbagai jenis minuman non-alkohol lainnya seperti soft drink berikut 
sajian makanan ringan lainnya. Karakteristik kafe ditinjau dari aspek bisnis kafe dapat dikelompokkan menjadi beberapa jenis, antara lain; automat restoran atau vendetarian, canteen atau kantin, café, cafetaria, chop steak atau steak house, cabaret atau nite club, coffe pot restoran, dellicatessent, dinner atau kereta makan, drive inn, grill café, wagon restaurant, tavern, common dan pizzeria.

Berikut kerangka kerja yang digunakan dalam penelitian ini, yang ditunjukkan pada gambar.

Kualitas Layanan (X)

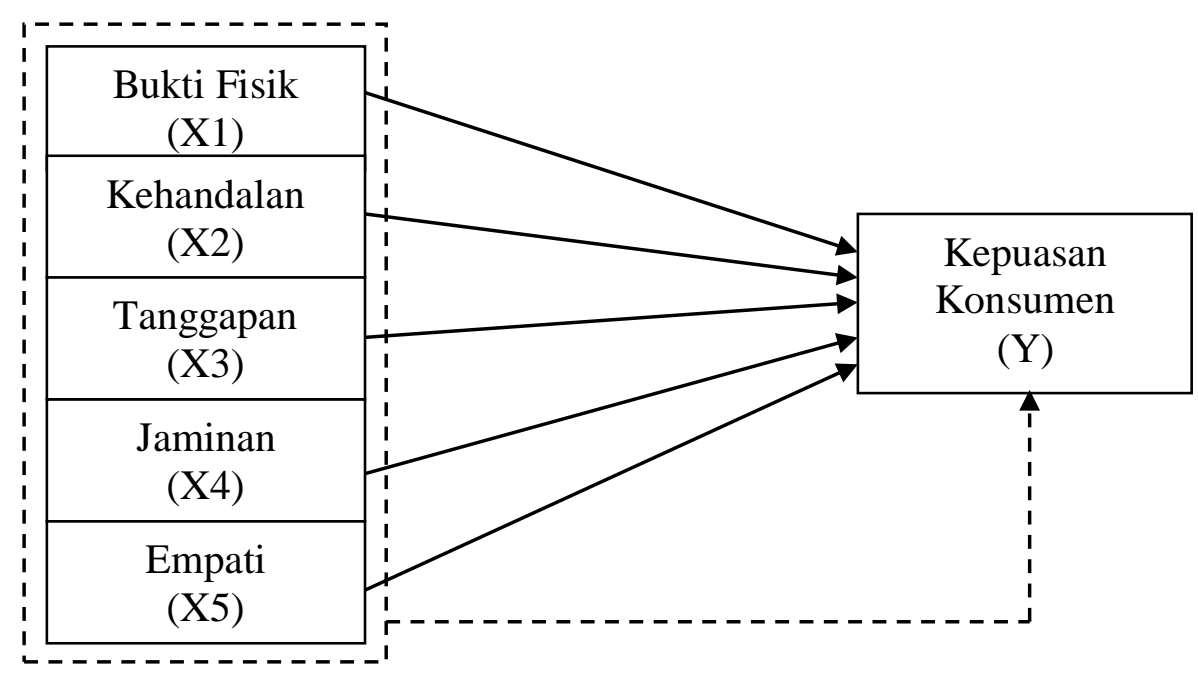

Gambar 3 Kerangka Berpikir

Berdasarkan kerangka teori di atas, maka hipotesis penelitian ini adalah sebagai berikut :

$\mathrm{H}_{1}$ : Kualitas layanan secara parsial berpengaruh signifikan terhadap kepuasan konsumen.

$\mathrm{H}_{2}$ : Kualitas layanan secara simultan berpengaruh signifikan terhadap kepuasan konsumen.

\section{METODE PENELITIAN}

\subsection{Populasi dan Sampel}

Populasi adalah keseluruhan jumlah yang terdiri atas objek atau subjek yang mempunyai karakteristik dan kualitas tertentu yang ditetapkan oleh peneliti untuk diteliti dan kemudian ditarik kesimpulannya (Sujarweni, 2015). Populasi dalam penelitian ini adalah konsumen Resto \& Cafe Rumah Laut Jayapura. Sampel adalah bagian dari sejumlah karakteristik yang dimiliki oleh populasi yang digunakan untuk penelitian. Dalam penelitian ini sebanyak 60 orang akan dijadikan responden untuk dimintai pendapatnya mengenai kualitas pelayanan di Resto \& Cafe Rumah Laut, mengacu pada acuan umum untuk menentukan ukuran sampel menurut Roscue, yaitu : 
a. Ukuran sampel lebih dari 30 dan kurang dari 500 adalah tepat untuk kebanyakan penelitian.

b. Dalam penelitian multivariate (termasuk analisis regresi berganda), ukuran sampel sebaiknya 10 kali lebih besar dari jumlah variabel dalam penelitian.

c. Untuk penelitian eksperimental sederhana dengan control eksperimen yang ketat, penelitian yang sukses adalah dengan ukuran sampel kecil antara 10 sampai dengan 20 .

Dalam penelitian ini, teknik pengambilan sampel yang digunakan yaitu simple random sampling. Dalam teknik ini pengambilan anggota sampel dan populasi dilakukan secara acak tanpa memperhatikan strata yang ada dalam populasi itu. (Sujarweni, 2015)

\subsection{Definisi Operasional}

Dalam penelitian ini variabel yang diteliti adalah kualitas layanan sebagai variabel bebas (independen variabel) yang terdiri dari lima variabel, yaitu: bukti fisik (X1), kehandalan (X2), tanggapan (X3), Jaminan (X4), dan Empati (X5). Adapaun variabel terikat Y (dependen variabel) yang terdiri dari satu variabel yaitu kepuasan konsumen.

\subsection{Teknik Analisis}

a. Uji Instrumen Penelitian

1) Uji Validitas

2) Uji Reliabilitas

b. Uji Asumsi Klasik

1) Uji Multikolineritas

2) Uji Heteroskedastisitas

3) Uji Normalitas

c. Regresi Linear Berganda

Regresi berganda merupakan sebuah teknik analisis data untuk mengetahui seberapa besar pengaruh variabel independen terhadap variabel dependen. Pada regresi linear berganda variabel independen lebih dari satu variabel (M, 2008). Adapun model persamaannya yaitu sebagai berikut.

$Y=a+b_{1} X_{1}+b_{2} X_{2}+b_{3} X_{3}+b_{4} X_{4}+b_{5} X_{5}+e$

Keterangan :

$\mathrm{Y}=$ Kepuasan Konsumen

$\mathrm{X}_{1}=$ Bukti Langsung (Tangible)

$\mathrm{X}_{2}=$ Kehandalan (Reliability)

$\mathrm{X}_{3}=$ Daya Tanggap (Responsiveness)

$\mathrm{X}_{4}=$ Jaminan (Assurance)

$\mathrm{X}_{5}=$ Kepedulian (Empathy)

$\mathrm{a}=$ Konstanta

$\mathrm{b}_{1}=$ Koefisien regresi $\left(\mathrm{X}_{1}\right)$ 


$$
\begin{aligned}
& b_{2}=\text { Koefisien regresi }\left(X_{2}\right) \\
& b_{3}=\text { Koefisien regresi }\left(X_{3}\right) \\
& b_{4}=\text { Koefisien regresi }\left(X_{4}\right) \\
& b_{5}=\text { Koefisien regresi }\left(X_{5}\right) \\
& e=\text { error }
\end{aligned}
$$

d. Uji Hipotesis
1) Uji T (Parsial)
2) Uji F (Simultan)
3) Uji Determinasi $\left(R^{2}\right)$

\section{HASIL DAN PEMBAHASAN}

\subsection{Hasil}

a. Deskripsi Karakteristik Demografi Responden

Sampel dalam penelitian ini berjumlah 60 responden yang merupakan konsumen Resto \& Café Rumah Laut Jayapura yang telah berkunjung minimal sekali. Penyeberan kuesioner dilakukan secara online dengan menggunakan media google form yang kemudian hanya boleh diisi oleh responden yang memenuhi kriteria pengisian. Gambaran mengenai responden yang menjadi sampel penelitian adalah sebagai berikut :

Tabel 1 Karakteristik Responden

\begin{tabular}{|l|c|r|}
\hline \multicolumn{1}{|c|}{ Jenis Kelamin } & Jumlah & Persentase \\
\hline Perempuan & 46 & $77 \%$ \\
\hline Laki-laki & 14 & $23 \%$ \\
\hline Total Usia & 60 & $100 \%$ \\
\hline \multicolumn{1}{|c|}{ Jumlah } & Presentase \\
\hline 15-25 tahun & 43 & $72 \%$ \\
\hline 26-35 tahun & 15 & $25 \%$ \\
\hline$>35$ tahun & 2 & $3 \%$ \\
\hline Total Pekerjaan & 60 & $100 \%$ \\
\hline & Jumlah & Presentase \\
\hline Pelajar/Mahasiswa & 37 & $62 \%$ \\
\hline Pegawai (swasta/negeri) & 16 & $27 \%$ \\
\hline Wirausaha & 4 & $7 \%$ \\
\hline Lainnya & 3 & $100 \%$ \\
\hline Total & 60 & $68 \%$ \\
\hline Penghasilan Dalam 1 Bulan & Jumlah & Presentase \\
\hline Di bawah Rp 3.000.000 & 41 & $12 \%$ \\
\hline Rp 4.000.000-Rp 6.000.000 & 12 & $100 \%$ \\
\hline Di atas Rp 6.000.000 & 7 & \\
\hline Total & 60 & \\
\hline
\end{tabular}


b. Deskripsi Variabel

Tabel 2 Deskripsi Variabel

\begin{tabular}{|c|c|c|c|c|c|c|}
\hline No & Kode Var & abel & SS & S & TS & STS \\
\hline \multirow{5}{*}{1} & \multirow{5}{*}{$\begin{array}{l}\text { Bukti Fisik } \\
\text { (X1) }\end{array}$} & $\mathrm{X} 1.1$ & $\begin{array}{c}28 \\
47 \% \\
\end{array}$ & $\begin{array}{c}32 \\
53 \% \\
\end{array}$ & $\begin{array}{c}0 \\
0 \%\end{array}$ & $\begin{array}{c}0 \\
0 \% \\
\end{array}$ \\
\hline & & $\mathrm{X} 1.2$ & $\begin{array}{c}15 \\
25 \%\end{array}$ & $\begin{array}{c}44 \\
73 \%\end{array}$ & $\begin{array}{c}1 \\
2 \%\end{array}$ & $\begin{array}{c}0 \\
0 \%\end{array}$ \\
\hline & & $\mathrm{X} 1.3$ & $\begin{array}{c}25 \\
42 \%\end{array}$ & $\begin{array}{c}31 \\
52 \%\end{array}$ & $\begin{array}{c}4 \\
7 \%\end{array}$ & $\begin{array}{c}0 \\
0 \%\end{array}$ \\
\hline & & X1.4 & $\begin{array}{c}20 \\
33 \%\end{array}$ & $\begin{array}{c}38 \\
63 \%\end{array}$ & $\begin{array}{c}2 \\
3 \%\end{array}$ & $\begin{array}{c}0 \\
0 \%\end{array}$ \\
\hline & & $\mathrm{X} 1.5$ & $\begin{array}{c}17 \\
28 \%\end{array}$ & $\begin{array}{c}39 \\
65 \%\end{array}$ & $\begin{array}{c}4 \\
7 \%\end{array}$ & $\begin{array}{c}0 \\
0 \%\end{array}$ \\
\hline \multirow{5}{*}{2} & \multirow{5}{*}{$\begin{array}{c}\text { Kehandalan } \\
\text { (X2) }\end{array}$} & $\mathrm{X} 2.1$ & $\begin{array}{c}12 \\
20 \%\end{array}$ & $\begin{array}{c}42 \\
70 \%\end{array}$ & $\begin{array}{c}5 \\
8 \%\end{array}$ & $\begin{array}{c}1 \\
2 \%\end{array}$ \\
\hline & & $\mathrm{X} 2.2$ & $\begin{array}{c}15 \\
25 \% \\
\end{array}$ & $\begin{array}{c}34 \\
57 \% \\
\end{array}$ & $\begin{array}{c}11 \\
18 \% \\
\end{array}$ & $\begin{array}{c}0 \\
0 \% \\
\end{array}$ \\
\hline & & $\mathrm{X} 2.3$ & $\begin{array}{c}13 \\
22 \%\end{array}$ & $\begin{array}{c}32 \\
53 \%\end{array}$ & $\begin{array}{c}15 \\
25 \%\end{array}$ & $\begin{array}{c}0 \\
0 \%\end{array}$ \\
\hline & & X2.4 & $\begin{array}{c}15 \\
25 \%\end{array}$ & $\begin{array}{c}43 \\
72 \%\end{array}$ & $\begin{array}{c}2 \\
3 \%\end{array}$ & $\begin{array}{c}0 \\
0 \%\end{array}$ \\
\hline & & $\mathrm{X} 2.5$ & $\begin{array}{c}11 \\
18 \% \\
\end{array}$ & $\begin{array}{c}34 \\
57 \% \\
\end{array}$ & $\begin{array}{c}13 \\
22 \% \\
\end{array}$ & $\begin{array}{c}2 \\
3 \% \\
\end{array}$ \\
\hline \multirow{3}{*}{3} & \multirow{3}{*}{$\begin{array}{c}\text { Tanggapan } \\
\text { (X3) }\end{array}$} & X3.1 & $\begin{array}{c}6 \\
10 \%\end{array}$ & $\begin{array}{c}36 \\
60 \%\end{array}$ & $\begin{array}{c}15 \\
25 \%\end{array}$ & $\begin{array}{c}3 \\
5 \%\end{array}$ \\
\hline & & X3.2 & $\begin{array}{c}24 \\
40 \%\end{array}$ & $\begin{array}{c}34 \\
57 \%\end{array}$ & $\begin{array}{c}2 \\
3 \%\end{array}$ & $\begin{array}{c}0 \\
0 \%\end{array}$ \\
\hline & & X3.3 & $\begin{array}{c}16 \\
27 \% \\
\end{array}$ & $\begin{array}{c}34 \\
57 \% \\
\end{array}$ & $\begin{array}{c}10 \\
17 \% \\
\end{array}$ & $\begin{array}{c}0 \\
0 \% \\
\end{array}$ \\
\hline \multirow{3}{*}{4} & \multirow{3}{*}{$\begin{array}{c}\text { Jaminan } \\
\text { (X4) }\end{array}$} & $\mathrm{X} 4.1$ & $\begin{array}{c}22 \\
37 \% \\
\end{array}$ & $\begin{array}{c}37 \\
62 \% \\
\end{array}$ & $\begin{array}{c}0 \\
0 \% \\
\end{array}$ & $\begin{array}{c}1 \\
2 \% \\
\end{array}$ \\
\hline & & $\mathrm{X} 4.2$ & $\begin{array}{c}18 \\
30 \%\end{array}$ & $\begin{array}{c}40 \\
67 \%\end{array}$ & $\begin{array}{c}2 \\
3 \%\end{array}$ & $\begin{array}{c}0 \\
0 \%\end{array}$ \\
\hline & & $\mathrm{X} 4.3$ & $\begin{array}{c}14 \\
23 \% \\
\end{array}$ & $\begin{array}{c}29 \\
48 \% \\
\end{array}$ & $\begin{array}{c}15 \\
25 \% \\
\end{array}$ & $\begin{array}{c}2 \\
3 \% \\
\end{array}$ \\
\hline \multirow{4}{*}{5} & \multirow{4}{*}{$\begin{array}{l}\text { Empati } \\
\text { (X5) }\end{array}$} & X5.1 & $\begin{array}{c}26 \\
27 \% \\
\end{array}$ & $\begin{array}{c}39 \\
65 \% \\
\end{array}$ & $\begin{array}{c}5 \\
8 \% \\
\end{array}$ & $\begin{array}{c}0 \\
0 \% \\
\end{array}$ \\
\hline & & $\mathrm{X} 5.2$ & $\begin{array}{c}12 \\
20 \%\end{array}$ & $\begin{array}{c}42 \\
70 \%\end{array}$ & $\begin{array}{c}6 \\
10 \%\end{array}$ & $\begin{array}{c}0 \\
0 \%\end{array}$ \\
\hline & & X5.3 & $\begin{array}{c}15 \\
25 \% \\
\end{array}$ & $\begin{array}{c}41 \\
68 \% \\
\end{array}$ & $\begin{array}{c}3 \\
5 \% \\
\end{array}$ & $\begin{array}{c}1 \\
2 \% \\
\end{array}$ \\
\hline & & X5.4 & $\begin{array}{c}12 \\
20 \% \\
\end{array}$ & $\begin{array}{c}35 \\
58 \% \\
\end{array}$ & $\begin{array}{c}11 \\
18 \% \\
\end{array}$ & $\begin{array}{c}2 \\
3 \% \\
\end{array}$ \\
\hline \multirow{2}{*}{6} & \multirow{2}{*}{$\begin{array}{c}\text { Kepuasan } \\
\text { Konsumen } \\
\text { (Y) }\end{array}$} & Y1 & $\begin{array}{c}11 \\
18 \%\end{array}$ & $\begin{array}{c}43 \\
72 \%\end{array}$ & $\begin{array}{c}6 \\
10 \%\end{array}$ & $\begin{array}{c}0 \\
0 \%\end{array}$ \\
\hline & & $\mathrm{Y} 2$ & $\begin{array}{c}15 \\
25 \% \\
\end{array}$ & $\begin{array}{c}36 \\
60 \% \\
\end{array}$ & $\begin{array}{c}8 \\
13 \% \\
\end{array}$ & $\begin{array}{c}1 \\
2 \% \\
\end{array}$ \\
\hline
\end{tabular}




\begin{tabular}{|c|c|c|c|c|c|c|}
\hline No & \multicolumn{2}{|c|}{ Kode Variabel } & SS & S & TS & STS \\
\hline & & Y3 & 15 & 41 & 3 & 1 \\
& & & $25 \%$ & $68 \%$ & $5 \%$ & $2 \%$ \\
\hline
\end{tabular}

c. Hasil Analisis Uji Instrumen

1) Uji Validitas

Validitas menyatakan keakuratan atau ketetapan. Artinya, data yang valid adalah data yang akurat atau data yang tepat (Sugiarto, 2017). Hasi $\mathrm{r}$ hitung dibandingkan dengan $\mathrm{r}$ tabel dimana $\mathrm{df}=\mathrm{n}-2$ dengan sig $5 \%$. Jadi besarnya $\mathrm{df}=30-2-28$ dengan signifikansi 0,05 maka didapat nilai $\mathrm{r}$ tabel sebesar 0,3610 .

Tabel 3 Uji Validitas

\begin{tabular}{|c|c|c|c|c|}
\hline Variabel & Indikator & R hitung & R tabel & Keterangan \\
\hline \multirow{5}{*}{$\begin{array}{l}\text { Bukti Fisik } \\
\text { (X1) }\end{array}$} & $\mathrm{X} 1.1$ & 0,606 & 0,3610 & Valid \\
\hline & $\mathrm{X} 1.2$ & 0,608 & 0,3610 & Valid \\
\hline & $\mathrm{X} 1.3$ & 0,499 & 0,3610 & Valid \\
\hline & $\mathrm{X} 1.4$ & 0,713 & 0,3610 & Valid \\
\hline & $\mathrm{X} 1.5$ & 0,781 & 0,3610 & Valid \\
\hline \multirow{5}{*}{$\begin{array}{c}\text { Kehandalan } \\
\text { (X2) }\end{array}$} & XX2.1 & 0,760 & 0,3610 & Valid \\
\hline & $\mathrm{X} 2.2$ & 0,856 & 0,3610 & Valid \\
\hline & $\mathrm{X} 2.3$ & 0,830 & 0,3610 & Valid \\
\hline & $\mathrm{X} 2.4$ & 0,758 & 0,3610 & Valid \\
\hline & $\mathrm{X} 2.5$ & 0,698 & 0,3610 & Valid \\
\hline \multirow{3}{*}{$\begin{array}{c}\text { Tanggapan } \\
\text { (X3) }\end{array}$} & X3.1 & 0,761 & 0,3610 & Valid \\
\hline & X3.2 & 0,790 & 0,3610 & Valid \\
\hline & X3.3 & 0,782 & 0,3610 & Valid \\
\hline \multirow{4}{*}{$\begin{array}{l}\text { Jaminan } \\
(\mathrm{X} 4)\end{array}$} & $\mathrm{X} 4.1$ & 0,798 & 0,3610 & Valid \\
\hline & $\mathrm{X} 4.1$ & 0,798 & 0,3610 & Valid \\
\hline & $\mathrm{X} 4.2$ & 0,696 & 0,3610 & Valid \\
\hline & $\mathrm{X} 4.3$ & 0,783 & 0,3610 & Valid \\
\hline \multirow{4}{*}{$\begin{array}{l}\text { Empati } \\
\text { (X5) }\end{array}$} & X5.1 & 0,886 & 0,3610 & Valid \\
\hline & $\mathrm{X} 5.2$ & 0,827 & 0,3610 & Valid \\
\hline & $\mathrm{X} 5.3$ & 0,785 & 0,3610 & Valid \\
\hline & $\mathrm{X} 5.4$ & 0,733 & 0,3610 & Valid \\
\hline \multirow{3}{*}{$\begin{array}{l}\text { Kepuasan } \\
\text { Konsumen } \\
\text { (Y) }\end{array}$} & Y.1 & 0,777 & 0,3610 & Valid \\
\hline & Y.2 & 0,932 & 0,3610 & Valid \\
\hline & Y.3 & 0,853 & 0,3610 & Valid \\
\hline
\end{tabular}

Berdasarkan tabel di atas yang diperoleh dari pengujian validitas instrumen penelitian, dapat diketahui bahwa semua indikator tiap variabel dinyatakan valid karena mempunyai nilai $r$ hitung $>r$ tabel.

2) Uji Reliabilitas 
Reliabilitas berkenaan dengan konsistensi, presisi, dan ketelitian. Dalam penelitian, reliabilitas berkaitan dengan derajat konsistensi data dan stabilitas data atau temuan. Suatu data dikatakan reliabel bila data tersebut konsistensi dan menunjukkan adanya ketelitian. Suatu variabel dinyatakan reliable jika menghasilkan nilai cronbach alpha >0,60 (Sugiarto, 2017).

Tabel 4 Uji Reliabilitas

\begin{tabular}{|c|l|c|c|c|}
\hline No & \multicolumn{1}{|c|}{ Variabel } & $\begin{array}{c}\text { Cronbach } \\
\text { Alpha }\end{array}$ & $\mathbf{0 , 6 0}$ & Keterangan \\
\hline 1 & Bukti Fisik (X1) & 0,750 & 0,60 & Reliabel \\
\hline 2 & Kehandalan (X2) & 0,827 & 0,60 & Reliabel \\
\hline 3 & Tanggapan (X3) & 0,650 & 0,60 & Reliabel \\
\hline 4 & Jaminan (X4) & 0,610 & 0,60 & Reliabel \\
\hline 5 & Empati (X5) & 0,804 & 0,60 & Reliabel \\
\hline 6 & Kepuasan Konsumen (Y) & 0,811 & 0,60 & Reliabel \\
\hline
\end{tabular}

Berdasarkan tabel di atas hasil yang diperoleh dari pengujian reliabilitas instrumen penelitian, dapat diketahui bahwa nilai cronbach alpha masing-masing variabel bukti fisik, kehandalan, tanggapan, jaminan, dan empati lebih besar dari 0,60, maka dapat dikatakan bahwa semua instrumen variabel penelitian tersebut adalah reliabel.

d. Hasil Uji Asumsi Klasik

1) Uji Multikolineritas

Uji multikolinieritas diperlukan untuk mengetahui ada tidaknya variabel independen yang memiliki kemiripan antar variabel independen dalam suatu model. Jika nilai VIF di sekitar angka 1-10 dan nilai tolerance $>0,10$, maka dikatakan tidak terdapat masalah multikolineritas (Sujarweni, 2015).

Tabel 5 Uji Multikolineritas

\begin{tabular}{|ll|r|r|}
\hline \multirow{2}{*}{\multicolumn{1}{|c|}{ Model }} & \multicolumn{2}{c|}{ Collinearity Statistics } \\
\cline { 2 - 4 } & Tolerance & \multicolumn{1}{c|}{ VIF } \\
\hline $1 \quad$ (Constant) & & \\
& Bukti Fisik & 0.486 & 2.056 \\
& Kehandalan & 0.379 & 2.638 \\
& Tanggapan & 0.379 & 2.639 \\
Jaminan & 0.475 & 2.106 \\
Empati & 0.524 & 1.908 \\
\hline
\end{tabular}

Berdasarkan tabel di atas hasil yang diperoleh dari pengujian multikolineritas diketahui bahwa nilai tolerance lebih besar dari 0.1 yang berarti variabel independen yang terdiri dari bukti fisik, kehandalan, tanggapan, jaminan dan empati tidak terjadi multikolineritas antar 
variabel independen. Hasil perhitungan VIF untuk masing - masing variabel independen lebih kecil dari 10, jadi dapat dikatakan bahwa tidak ada multikolineritas antar variabel independen dalam regresi.

2) Uji Heteroskedastisitas

Heteroskedastisitas menguji terjadinya perbedaan variance residual suatu periode pengamatan ke periode pengamatan yang lain. Cara memprediksi ada tidaknya heteroskedastisitas pada suatu model dapat dilihat dengan pola gambar Scatterplot, regresi yang tidak terjai heteroskedastisitas jika titik-titik data menyebar di atas dan di bawah atau di sekitar angka 0, titik-titik data tidk mengumpul hanya di atas ata di bawah saja, penyebaran titik-titik data tidak boleh membentuk pola bergelombang melebar kemudian menyempit dan melebar kembali, penyebaran titik-titik data tidak berpola (Sujarweni, 2015).

Scatterplot

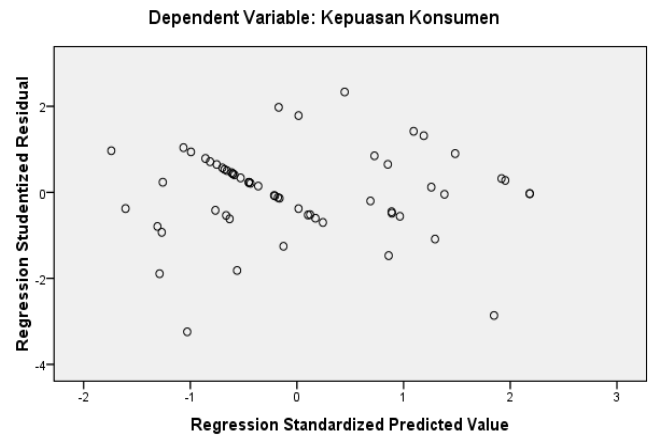

Gambar 3 Uji Heteroskedastisitas

Berdasarkan gambar dapat dikatakan bahwa tidak terjadi heteroskedastisitas pada model regresi, sehingga model regresi layak digunakan untuk memprediksi kepuasan konsumen berdasarkan variabel bebas.

Tabel 6 Uji Heteroskedastisitas

Coefficients $^{\text {a }}$

\begin{tabular}{|c|c|c|c|c|c|}
\hline \multirow[b]{2}{*}{ Model } & \multicolumn{2}{|c|}{$\begin{array}{l}\text { Unstandardized } \\
\text { Coefficients }\end{array}$} & \multirow{2}{*}{\begin{tabular}{|c|}
$\begin{array}{c}\text { Standardized } \\
\text { Coefficients }\end{array}$ \\
Beta \\
\end{tabular}} & \multirow[b]{2}{*}{$\mathrm{T}$} & \multirow[b]{2}{*}{ Sig. } \\
\hline & B & Std. Error & & & \\
\hline $1 \quad$ (Constant) & 0.965 & 0.756 & & 1.276 & 0.207 \\
\hline Bukti Fisik & 0.050 & 0.060 & 0.155 & 0.826 & 0.413 \\
\hline Kehandalan & 0.037 & 0.055 & 0.145 & 0.680 & 0.500 \\
\hline Tanggapan & -0.118 & 0.094 & -0.268 & -1.256 & 0.214 \\
\hline Jaminan & 0.005 & 0.083 & 0.012 & 0.062 & 0.951 \\
\hline Empati & -0.052 & 0.062 & -0.152 & -0.840 & 0.405 \\
\hline
\end{tabular}


Berdasarkan tabel di atas dapat diketahui bahwa nilai signifikansi untuk variabel bukti fisik sebesar 0.413, variabel kehandalan sebesar 0.500 , variabel tanggapan sebesar 0.214 , variabel jaminan sebesar 0.951 dan variabel empati sebesar 0.405. Semua variabel mempunyai tingkat signifikasi > 0.05, maka dapat dikatakan bahwa pada model regresi tidak terjadi heteroskedastisitas.

3) Uji Normalitas

Uji normalitas bertujuan untuk menguji apakah dalam model regresi variabel pengganggu atau residual memiliki. distribusi normal. Uji normalitas bertujuan untuk menguji apakah dalam model regresi variabel pengganggu atauresidual memiliki. distribusi normal. Terdapat dua cara untuk mendeteksi apakah residual berdistribusi normal atau tidak, yakni dengan menggunakan analisis grafik dan uji statistik. Dalam analisis grafik untuk melihat normalitas residual adalah dengan melihat grafik histogram dan normal probality plot. Distribusi normal akan membentuk satu garis lurus diagonal, dan ploting data residual akan dibandingkan dengan garis diagonal.

$$
\text { Histogram }
$$

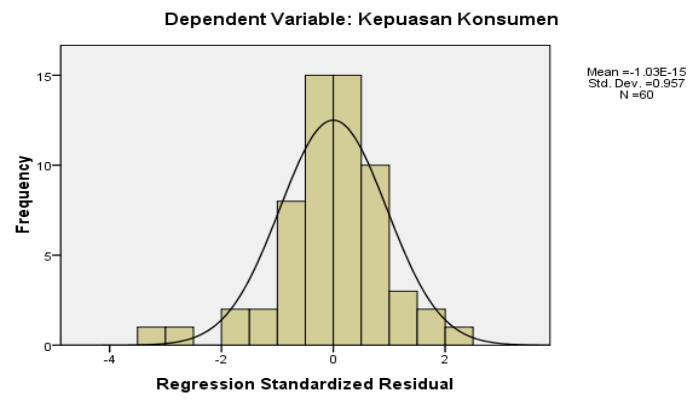

Gambar 4 Uji Normalitas

Berdasarkan gambar di atas, Histogram Regression Standardized Residual membentuk kurva seperti lonceng, maka nilai residual tersebut dinyatakan normal atau data berdistribusi normal.

Normal P-P Plot of Regression Standardized Residual

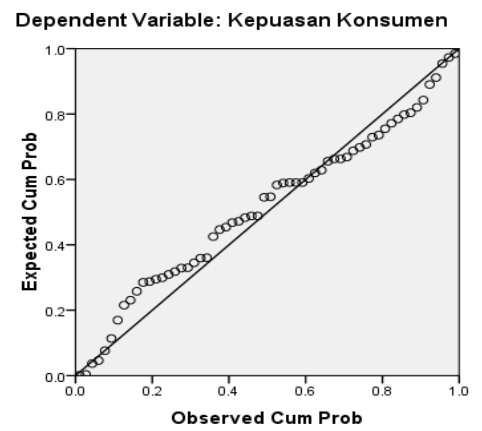


Berdasarkan gambar di atas dapat dilihat bahwa titik-titik yang menyebar di sekitar garis diagonal dan penyebaran titik-titik data searah dengan garis diagonal menandakan bahwa model asumsi regresi memenuhi asumsi normalitas dan model regresi layak untuk menganalisis pengaruh variabel-variabel independen (bukti fisik, kehandalan, tanggapan, jaminan dan empati) terhadap variabel dependen (kepuasan konsumen).

e. Hasil Uji Regresi Linear Berganda

Analisis regresi linier berganda digunakan untuk menentukan persamaan regresi yang terbentuk dalam penelitian ini, maka dapat diketahui dengan melihat hasil uji regresi linear berganda di bawah ini:

Tabel 6 Uji Regresi Linear Berganda

Coefficients $^{\text {a }}$

\begin{tabular}{|c|c|c|c|c|c|}
\hline \multirow{2}{*}{ Model } & \multicolumn{2}{|c|}{$\begin{array}{c}\text { Unstandardized } \\
\text { Coefficients } \\
\end{array}$} & \multirow{2}{*}{$\begin{array}{c}\begin{array}{c}\text { Standardized } \\
\text { Coefficients }\end{array} \\
\text { Beta }\end{array}$} & \multirow[b]{2}{*}{$\mathrm{T}$} & \multirow[b]{2}{*}{ Sig. } \\
\hline & B & Std. Error & & & \\
\hline 1(Constant) & -0.977 & 1.156 & & -0.845 & 0.402 \\
\hline Bukti Fisik & 0.186 & 0.092 & 0.238 & 2.023 & 0.048 \\
\hline Kehandalan & 0.168 & 0.084 & 0.265 & 1.992 & 0.051 \\
\hline Tanggapan & -0.062 & 0.143 & -0.058 & -0.434 & 0.666 \\
\hline Jaminan & 0.345 & 0.128 & 0.322 & 2.702 & 0.009 \\
\hline Empati & 0.158 & 0.094 & 0.191 & 1.682 & 0.098 \\
\hline
\end{tabular}

Berdasarkan tabel di atas maka persamaan regresi yang terbentuk adalah :

$Y=a+b_{1} X_{1}+b_{2} X_{2}+b_{3} X_{3}+b_{4} X_{4}+b_{5} X_{5}+e$

$Y=-0,977+0.186 X_{1}+0.168 X_{2}+-0.062 X_{3}+0,345 X_{4}+0,158 X_{5}$

\section{f. Hasil Uji Hipotesis}

1) Uji $\mathrm{T}$ (Parsial)

Uji t adalah pengujian koefisien regresi parsial individual yang digunakan untuk mengetahui pengaruh variabel indepen terhadap variabel dependen.

Tabel 7 Uji T.

Coefficients $^{\mathrm{a}}$

\begin{tabular}{|c|c|c|c|c|}
\hline Model & $\begin{array}{c}\text { Unstandardized } \\
\text { Coefficients }\end{array}$ & $\begin{array}{c}\text { Standardized } \\
\text { Coefficients }\end{array}$ & $\mathrm{t}$ & Sig. \\
\hline
\end{tabular}




\begin{tabular}{|c|c|c|c|c|c|}
\hline & B & Std. Error & Beta & & \\
\hline (Constant) & -0.977 & 1.156 & & -0.845 & 0.402 \\
\hline Bukti Fisik & 0.186 & 0.092 & 0.238 & 2.023 & 0.048 \\
\hline Kehandalan & 0.168 & 0.084 & 0.265 & 1.992 & 0.051 \\
\hline Tanggapan & -0.062 & 0.143 & -0.058 & -0.434 & 0.666 \\
\hline Jaminan & 0.345 & 0.128 & 0.322 & 2.702 & 0.009 \\
\hline Empati & 0.158 & 0.094 & 0.191 & 1.682 & 0.098 \\
\hline
\end{tabular}

Berdasarkan tabel hasil uji-t menunjukkan bahwa bukti fisik dan variabel jaminan secara parsial mempengaruhi kepuasan konsumen, dengan tingkat signifikansi masing-masing adalah 0,048<0,05 dan 0,009 $<0,05$. Sementara variabel reliabilitas memiliki tingkat signifikansi sebesar 0,051, variabel respon memiliki tingkat signifikansi sebesar 0,666 dan variabel empati memiliki tingkat signifikansi sebesar 0,098 secara parsial tidak signifikan mempengaruhi variabel kepuasan konsumen.

2) Uji F (Simultan)

Uji $\mathrm{F}$ adalah pengujian signifikan persamaan yang digunakan untuk mengetahui seberapa besar pengaruh variabel bebas secara bersama-sama terhadap variabel terikat.

Tabel 8 Uji F

ANOVA $^{b}$

\begin{tabular}{|l|r|r|r|c|c|}
\hline \multicolumn{1}{|c|}{ Model } & \multicolumn{1}{|c|}{$\begin{array}{c}\text { Sum of } \\
\text { Squares }\end{array}$} & Df & $\begin{array}{c}\text { Mean } \\
\text { Square }\end{array}$ & F & Sig. \\
\hline 1Regression & 89.972 & 5 & 17.994 & 18.919 & $0.000^{2}$ \\
Residual & 51.361 & 54 & 0.951 & & \\
Total & 141.333 & 59 & & & \\
\hline
\end{tabular}

Sumber : Hasil Olah Data Primer, 2020.

Berdasarkan tabel uji f menunjukkan bahwa nilai f-hitung lebih besar dari nilai f-tabel $(18,919>2,38)$ dengan tingkat signifikansi 0,000 $<0,05$ berarti bahwa kualitas layanan secara bersamaan memiliki pengaruh yang signifikan terhadap kepuasan konsumen

3) Uji Determinasi $\left(R^{2}\right)$

Koefisien Determinasi digunakan untuk mengetahui presentasi perubahan variabel tidak bebas (Y) yang disebabkan oleh variabel bebas (X).

Tabel 9 Uji Determinasi

Model Summary

\begin{tabular}{|c|c|c|c|c|}
\hline Model & $\mathrm{R}$ & $\mathrm{R}$ Square & Adjusted R Square & Std. Error of the Estimate \\
\hline 1 & $.798^{\mathrm{a}}$ & 00.637 & 0.603 & 0.975 \\
\hline
\end{tabular}


Dari tabel di atas, didapatkan nilai $R$ Square (koefisien determinasi) sebesar 00,637. Hasil ini berarti variabel independen yaitu bukti fisik, kehandalan, tanggapan, jaminan dan empati hanya menjelaskan sebesar $63,7 \%$ terhadap variabel dependen yaitu kepuasan konsumen, sedangkan sisanya sebesar 36,3\% (100\%-63,7\%) dijelaskan oleh variabel lain yang tidak disertakan dalam penelitian ini. Hasil koefisien determinasi $\left(\mathrm{R}_{2}\right)$ dengan nilai $R$ Square sebesar 00,637 atau $63,7 \%$ ini artinya koefisien determinasi dari variabel penelitian menunjukkan tingkat korelasi yang kuat.

\subsection{Pembahasan}

Penelitian dilakukan untuk menganalisis pengaruh kualitas layanan terhadap kepuasan konsumen Resto dan Café Rumah Laut Jayapura, dengan menggunakan model Service Quality yang terdiri dari lima dimensi pengukur kepuasan, yaitu bukti fisik, kehandalan, tanggapan, jaminan dan empati. Hasil penelitian menunjukkan bahwa variabel kepuasan konsumen dapat dijelaskan oleh kualitas layanan sebesar 63,7\%, sedangkan sisanya 36,3\% dijelaskan oleh faktor lain.

Hasil penelitian menunjukkan bahwa terdapat pengaruh yang siginifikan secara parsial atau sendiri antara variabel bukti fisik terhadap kepuasan konsumen. Hasil ini didukung penelitian yang dilakukan oleh Meutia Dewi dalam jurnal yang meneliti Pengaruh Kualitas Pelayanan terhadap Kepuasan Pasien Pengguna BPJS pada Rumah Sakit Rehabilitasi Medik Kabupaten Aceh Timur, dimana pengaruh bukti fisik secara parsial memberikan pengaruh yang signifikan terhadap kepuasan kepuasan pasien Rumah Sakit Rehabilitasi Medik.

Dalam penelitian ini menunjukkan bahwa tidak terdapat pengaruh yang siginifikan secara parsial atau sendiri antara variabel kehandalan terhadap kepuasan konsumen. Didukung penelitian yang dilakukan oleh Januar Efendi Panjaitan dan Ai Lili Yuliati dalam jurnal yang meneliti Pengaruh Kualitas Pelayanan Terhadap Kepuasan Pelanggan Pada Jne Cabang Bandung, dimana pengaruh kehandalan secara parsial tidak memberikan pengaruh yang signifikan terhadap kepuasan kepuasan pelanggan pada Jne Cabang Bandung.

Dalam penelitian ini juga menunjukkan bahwa tidak terdapat pengaruh yang siginifikan secara parsial atau sendiri antara variabel tanggapan terhadap kepuasan konsumen. Hasil ini didukung penelitian yang dilakukan oleh Safrizal dalam jurnal yang berjudul Analisis Pengaruh Kualitas Pelayanan terhadap Kepuasan Konsumen pada Depot Air Minum Isi Ulang Tirta Tamiang di Kecamatan Tenggulun, dalam hasil penelitiannya menunjukkan bahwa variabel tanggapan berpengaruh tidak signifikan terhadap kepuasan konsumen.

Dalam penelitian ini menunjukkan bahwa terdapat pengaruh yang siginifikan secara parsial atau sendiri antara variabel jaminan terhadap 
kepuasan konsumen. Hasil ini didukung penelitian yang dilakukan oleh Dwi Aliyyah Apriyani dan Sunarti dalam jurnal yang meneliti Pengaruh Kualitas Pelayanan Terhadap Kepuasan Konsumen (Survei Pada Konsumen The Little A Coffee Shop Sidoarjo), dimana pengaruh jaminan secara parsial memberikan pengaruh yang signifikan terhadap kepuasan kepuasan konsumen The Little A Coffee Shop Sidoarjo.

Dalam penelitian ini menunjukkan bahwa tidak terdapat pengaruh yang siginifikan secara parsial atau sendiri antara variabel empati terhadap kepuasan konsumen. Hasil ini , didukung penelitian yang dilakukan oleh Tri Ulfa Wardani dalam skripsi yang meneliti Pengaruh Kualitas Pelayanan Terhadap Kepuasan Konsumen pada Bisnis Jasa Transportasi Gojek (Studi Kasus Mahasiswa Febi Uin Sumatera Utara), dimana pengaruh empati secara parsial tidak memberikan pengaruh yang signifikan terhadap kepuasan konsumen transportasi gojek.

Hasil penelitian ini juga menunjukkan bahwa terdapat pengaruh yang siginifikan secara simultan atau bersama-sama antara variabel kualitas layanan yang meliputi bukti fisik, kehandalan, tanggapan, jaminan dan empati terhadap kepuasan konsumen Resto \& Café Rumah Laut Jayapura. Hasil ini sesuai dengan teori yang dikatakan oleh Kotler bahwa dalam menentukan tingkat kepuasan konsumen terdapat lima faktor utama yang harus diperhatikan oleh perusahaan, salah satunya yaitu kualitas pelayanan. Sesuai juga dengan teori menurut Pasaruman dan Zeithaml yang mengatakan bahwa dimensi pengukuran kepuasan dalam melayani konsumen adalah bukti fisik, kehandalan, tanggapan, jaminan dan empati.

Konsep Islam mengajarkan bahwa dalam memberikan pelayanan dari usaha yang dijalankan baik itu berupa barang atau jasa jangan memberikan yang buruk atau tidak berkualitas, melainkan memberi pelayanan yang berkualitas kepada orang lain. Pihak Resto \& Cafe Rumah Laut Jayapura telah memberikan pelayanan yang baik dan berkualitas. Contohnya yaitu dari segi sikap karyawan yang ramah dan sopan dalam berinteraksi dengan semua konsumen, dimulai saat masuk ke dalam café \& resto sampai keluar dari café \& resto, membuat konsumen merasa nyaman berada di Resto \& Cafe Rumah Laut Jayapura. Kerapihan, keindahan dan kebersihan yang selalu diperhatikan oleh pihak Resto \& Cafe Rumah Laut Jayapura, baik dari segi tempat maupun makanan dan minuman yang halal.

\section{KESIMPULAN DAN SARAN}

Berdasarkan hasil analisis data dan pengujian hipotesis yang telah dilakukan, maka secara garis besar dapat disimpulkan bahwa pengaruh kualitas layanan secara parsial terhadap kepuasan konsumen Resto \& Cafe Rumah Laut Jayapura adalah masing-masing untuk variabel bukti fisik dan jaminan berpengaruh secara signifikan, sedangkan untuk variabel kehandalan, tanggapan dan empati masing- 
masing tidak berpengaruh secara signifikan terhadap kepuasan konsumen Resto \& Cafe Rumah Laut Jayapura. Pengaruh kualitas layanan secara simultan terhadap kepuasan konsumen Resto \& Cafe Rumah Laut Jayapura adalah berpengaruh secara signifikan.

Berdasarkan kesimpulan yang telah dipaparkan di atas, maka disarankan untuk pihak Resto \& Cafe Rumah Laut Jayapura diharapkan mampu memperbaiki atribut-atribut kualitas pelayanan yang telah diberikan pada setiap dimensinya terutama atribut yang memberikan pengaruh paling rendah terhadap kepuasan konsumen, yaitu tanggapan. Misalnya dengan menambah jumlah karyawan dibagian dapur agar pesanan konsumen dapat diantar dengan cepat. Diharapkan Resto \& Cafe Rumah Laut Jayapura tetap mempertahankan atribut kualitas pelayanan jaminan karena memberikan pengaruh paling dominan terhadap kepuasan konsumen. Diharapkan lembaga kampus IAIN Fattahul Muluk Papua, khusunya Fakultas Ekonomi dam Bisnis Islam agar memperbanyak menyediakan literatur dengan edisi terbaru tentang kualitas pelayanan dan kepuasan konsumen, untuk mempermudah peneliti selanjutnya dalam mencari sumber rujukan teori. Masyarakat sebagai konsumen diharapkan lebih bijak dalam berkonsumsi, seperti tidak memaksakan keadaan ekonomi untuk memenuhi sebuah gaya hidup. Peneliti selanjutnya diharapkan untuk mengembangkan penelitian dengan meneliti variabel lain yang mempengaruhi kepuasan konsumen, misalnya faktor harga, lokasi atau promosi dan diharapkan untuk meneliti pada populasi konsumen yang lebih luas, seperti meneliti konsumen lama maupun konsumen baru yang telah berkunjung ke Resto \& Cafe Rumah Laut Jayapura.

\section{DAFTAR REFERESI}

Anggraeni, Dewi Mei. (2019). Pengaruh Pelayanan dan Promosi Terhadap Minat Kunjung Kembali Wisatawan Dengan Kepuasan Pengunjung Sebagai Variabel Intervening Pada Wisata Pemancingan Dewandaru Kecamatan Gunung Pati Semarang. UIN Walisongo Semarang

Apriyani , Dwi Aliyyah dan Sunarti. (Oktober 2017). Pengaruh Kualitas Pelayanan Terhadap Kepuasan Konsumen Survei pada Konsumen The Little a Coffe Shop Sidoarjo. Jurnal Administrasi Bisnis, Vol. 51, No.2 Oktober (2017): 6

Brian, Rio. Pengertian Modernisasi: Tujuan, Ciri-Ciri dan Dampaknya Pada Dunia Usaha. www.maxmanroe.com

Daryanto dan Ismanto Setyabudi (2014) Konsumen dan Pelayanan Prima. Yogyakarta: Penerbit Gava Media

David W , Craven. (1996). Pemasaran Strategis. Jakarta : Erlangga, 1996 
Direktorat Perlindungan Konsumen Republik Indonesia, Undang-Undang Perlindungan Konsumen Nomor 8 Tahun 1999 Tentang Perlindungan Konsumen.

Djazifah, Nur. (2012). Modul Pembelajaran Sosiologi Proses Perubahan Sosial di Masyarakat. Yogyakarta : Lembaga Penelitian dan Pengabdian Kepada Masyarakat Fauroni, R. Lukman. (2006). Etika Bisnis dalam Al-Qur'an. Yogyakarta: Pustaka Pesantren

Iqbal, Muhammad. (2004). Pelayanan yang memuaskan. Jakarta: Elex Media Komputindo Kelompok Gramedia

Kementrian Agama Republik Indonesia. (2015). Al-Qur'an Dan Terjemahan Dilengkapi Tajwid. Jakarta: Dharma Art

Kotler, Philip dan Gary Armstrong. (2001). Prinsip-Prinsip Pemasaran, Jakarta : Erlangga

Lauw, Jessica dan Yohanes Sondang Kunto. (2013). Analisa Pengaruh Kualitas Layanan Terhadap Kepuasan Pelanggan di The Light Cup café Surabaya Town Square dan The Square Surabaya. Jurnal Manajemen Pemasaran, Vol.1, No.1

M, Muhammad. (2008). Metodologi Penelitian Ekomomi Islam Pendektan Kuantitatif. Depok: Raja Grafindo

Rahmadani, Helza. (2016). Persepsi Masyarakat Terhadap Aktivitas Café di Gampong Ie Masen Kareng Kec. Ulee Kareng Kota Banda Aceh. UIN Ar-Raniry Darussalam Banda Aceh

Sadriyah. (2018). Pengaruh Kualitas Pelayanan Terhadap Kepuasan Pelanggan. UIN Sultan Maulana Hasanuddin Banten

Sari, Mitha Destika. Pengaruh Kualitas Layanan Terhadap Loyalitas Konsumen Pada café D'puncak di Samarinda. Universitas 17 Agustus 1945 Samarinda

Situmeang, Lina Sari. (2017). Pengaruh Kualitas Pelayanan, Harga Dan Lokasi Terhadap Kepuasan Konsumen Pada Rumah Makan Istana Hot Plate Medan. UIN Medan Sumatera Utara

Sugiarto. (2017). Metodologi Penelitian Bisnis. Yogyakarta: Penerbit ANDI, 2017

Sujarwen, V. Wiratna. (2015). Metodologi Penelitian Bisnis \& Ekonomi. Yogyakarta : Pustakabarupres

Tjiptono, Fandy dan Gregorius Chandra (2019). Service Quality \& Customer Satisfaction-Edisi 5. Yogyakarta : Penerbit ANDI

Traveloka. Rumah Laut Cafe \& Retoran. www.traveloka.com 
Tripadvisori. Restoran Terpopueler di Jayapura. www.tripadvisori.co.id

Wood, Ivonne. (2009). Layanan Pelanggan. Yogyakarta: Graha Ilmu 